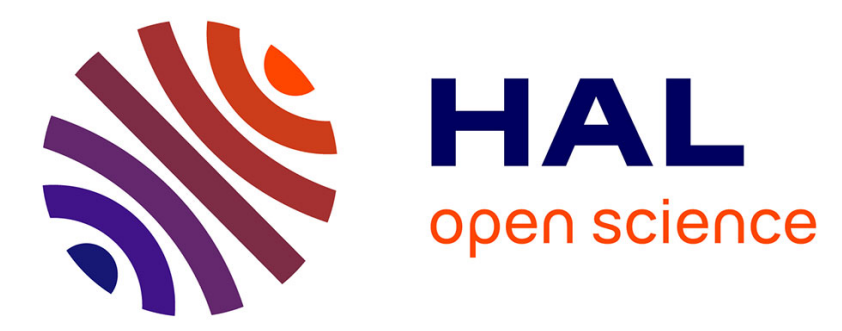

\title{
Social foraging and habitat use by a long-distance passerine migrant, Whinchat, at a spring stopover site on the SE Adriatic coast
}

Urša Koce, Damijan Denac

\section{- To cite this version:}

Urša Koce, Damijan Denac. Social foraging and habitat use by a long-distance passerine migrant, Whinchat, at a spring stopover site on the SE Adriatic coast. Journal für Ornithologie = Journal of Ornithology, 2010, 151 (3), pp.655-663. 10.1007/s10336-010-0506-z . hal-00573487

\section{HAL Id: hal-00573487 \\ https://hal.science/hal-00573487}

Submitted on 4 Mar 2011

HAL is a multi-disciplinary open access archive for the deposit and dissemination of scientific research documents, whether they are published or not. The documents may come from teaching and research institutions in France or abroad, or from public or private research centers.
L'archive ouverte pluridisciplinaire HAL, est destinée au dépôt et à la diffusion de documents scientifiques de niveau recherche, publiés ou non, émanant des établissements d'enseignement et de recherche français ou étrangers, des laboratoires publics ou privés. 


\title{
Social foraging and habitat use by a long-distance passerine migrant, Whinchat Saxicola rubetra, at a spring stopover site on the SE Adriatic coast
}

\author{
Urša Koce $\cdot$ Damijan Denac
}

Received: 4 May 2009/Revised: 27 November 2009/ Accepted: 9 February 2010/Published online: 4 March 2010

(C) Dt. Ornithologen-Gesellschaft e.V. 2010

\begin{abstract}
The preference for foraging in groups and the effect of physiognomic factors of a habitat on its use by foraging Whinchats (Saxicola rubetra) was studied during spring migration stopover in a mosaic cultural landscape at the SE Adriatic coast. Every record of spatially distinct Whinchats, either a solitary individual or a group, was referred to as a Whinchat unit. The units were classified as intensively foraging, less intensively foraging or non-foraging and divided into four size classes. The effect of physiognomic habitat factors on use of habitat by foraging Whinchat units was modelled. All possible additive models using logit link function were constructed from five independent physiognomic variables: (1) natural perches (NP), (2) artificial perches (AP), (3) high herbal vegetation (HHV), (4) open bushes (OB) and (5) heterogeneity of vegetation types (HVT). Variables HHV and OB were included simultaneously in the models. Models that were substantially supported by the data were selected according to second order Akaike's information criterion $\mathrm{AIC}_{\mathrm{c}}$. Two such models contained variable(s) (1) NP and (2) $\mathrm{NP}+\mathrm{AP}$. The relative importance weights of physiognomic variables NP, AP, HVT, HHV and OB were 1, 0.38, $0.24,0.13$ and 0.13 , respectively. Perches were thus the most important physiognomic habitat factor affecting habitat use by Whinchats in a mosaic cultural landscape. The great majority of Whinchats foraged in groups and the proportion of intensively foraging Whinchat units increased with unit size, leading to the conclusion that
\end{abstract}

Communicated by F. Bairlein.

U. Koce $(\bowtie) \cdot$ D. Denac

National Institute of Biology, Večna pot 111,

1000 Ljubljana, Slovenia

e-mail: ukoce@nib.si
Whinchats preferred social to solitary foraging on the spring stopover at the SE Adriatic coast.

Keywords Whinchat (Saxicola rubetra).

Spring migration - Social foraging · Habitat use ·

Effect of physiognomic habitat factors

\section{Introduction}

Birds adapt their migration strategies mainly to minimise overall journey time, energy consumption or predation risk, or combinations of these (Alerstam and Lindström 1990).

Stopovers between migratory flights are essential for birds to refuel, take up water and rest (Newton 2008), but also account for the majority of time and energy spent on the entire migration (Hedenström and Alerstam 1997; Alerstam and Hedenström 1998; Wikelski et al. 2003). Stopover strategies that minimise these expenditures are therefore favoured in evolution. Behavioural responses such as social foraging (Ekman and Hake 1988; Szekely et al. 1991) and selection of high quality habitats (Schaub and Jenni 2000) are involved in successful accomplishment of a stopover.

Presence of competitors limits the amount of food available to an individual but it can still be favourable for birds to forage in flocks. Potential payoffs of social foraging for a bird on migration are improved searching for food, enhanced capture and consumption of food, reduced time and energy costs of foraging or increased protection from predators (Ekman and Hake 1988; Giraldeau and Caraco 2000). Whinchats (Saxicola rubetra) are territorial in the breeding season and on the wintering grounds, but in the post-breeding season they form mixed flocks of adults and juveniles (Bastian and Bastian 1996) and often forage 
in flocks during migration (Glutz von Blotzheim 1988). There is some evidence that the foraging efficiency of Whinchats on autumn migration stopovers is higher in larger groups (Draulans and van Vessem 1982), but it is unknown whether social foraging is advantageous and preferred to solitary foraging during spring migration, which is quicker than autumn migration (Bastian and Bastian 1996), and where an effective time and energy use is expected.

Selection of habitat by birds at migration stopover sites is a complex decision-making process affected by several factors (Hutto 1985a; Maccarone and Brzorad 2005; Chernetsov 2006). Food abundance is of crucial importance (Bibby and Green 1981; Martin and Karr 1986; Delingat and Dierschke 2000), but the physiognomy of a microhabitat may be equally important for species with specific morphological or behavioural constraints (Bairlein 1992; Block and Brennan 1993; Chernetsov 2006). Intra- and interspecific interactions, particularly predation risk (Suhonen 1993; Walther and Gosler 2001) and competition (Hutto 1985b; Martin and Karr 1986; Yong et al. 1998), often influence selection of foraging habitat. Whinchats select specific habitats at migration stopover sites in European cultural landscapes (Draulans and van Vessem 1982; Bairlein 1983; Duckworth 1994), but the specific environmental factors bearing on this selection are unknown.

The Whinchat breeds in the major part of Europe and northwest Asia and it winters in sub-Saharan Africa (Bastian and Bastian 1996). Migration through southeast Europe is largely unknown. Birds passing this region in spring are most probably travelling directly from northern Africa to the eastern part of the species' breeding range (Glutz von Blotzheim 1988). West, central and some east European populations of Whinchats have declined substantially in the past decades (BirdLife International 2004). Loss of breeding habitats is recognised as the main cause for the decline, and attempts have been made to mitigate this process (Müller et al. 2005; Britschgi et al. 2006; Horch et al. 2008). Loss of high quality habitats at important stopover sites can substantially reduce the success of migration (Moore et al. 1995) and therefore add to the decline of populations. Basic information on habitat selection and life-history characteristics throughout the Whinchat's range is therefore needed for long-term conservation of the species (Moore et al. 1995; Donovan and Thompson 2001).

The aim of our study was (1) to test whether Whinchats favour social foraging during the spring migration stopover and how flocking affects their foraging activity in heterogeneous environment, and (2) to assess the importance of physiognomic habitat factors in Whinchats' foraging habitat selection in the mosaic cultural landscape on the SE Adriatic coast.

\section{Methods}

\section{Study area}

The study area was located in the mosaic cultural landscape of the Montenegrin coast in the hinterland of Velika plaža, a sandy beach extending $10 \mathrm{~km}$ south-eastwards from the city of Ulcinj $\left(41.89^{\circ} \mathrm{N}, 19.30^{\circ} \mathrm{E}\right)$ (Fig. 1). The area is a part of the delta of the Bojana-Buna river, recently recognised as an area of great ecological value with an extraordinarily rich bird community (Schneider-Jacoby et al. 2006). Among 237 bird species recorded, 52 are regular passage migrants, including the Whinchat. The weather during the study period was rather constant, the majority of days being sunny with moderate winds and midday temperatures between 22 and $27^{\circ} \mathrm{C}$.

Foraging and use of habitat by migrating Whinchats were studied at four plots, sized 14, 24, 31 and 31 ha (Fig. 1). Aerial distances between adjacent plots were 1.3, 0.7 and $0.8 \mathrm{~km}$.

\section{Whinchat censuses}

The censuses of Whinchats were carried out between 5 and 24 April 2007, during the first half of the passage of the
Fig. 1 Left Adriatic region and location of the study area (circle). Right Part of the delta of Bojana-Buna river and positions of study plots (A-D)

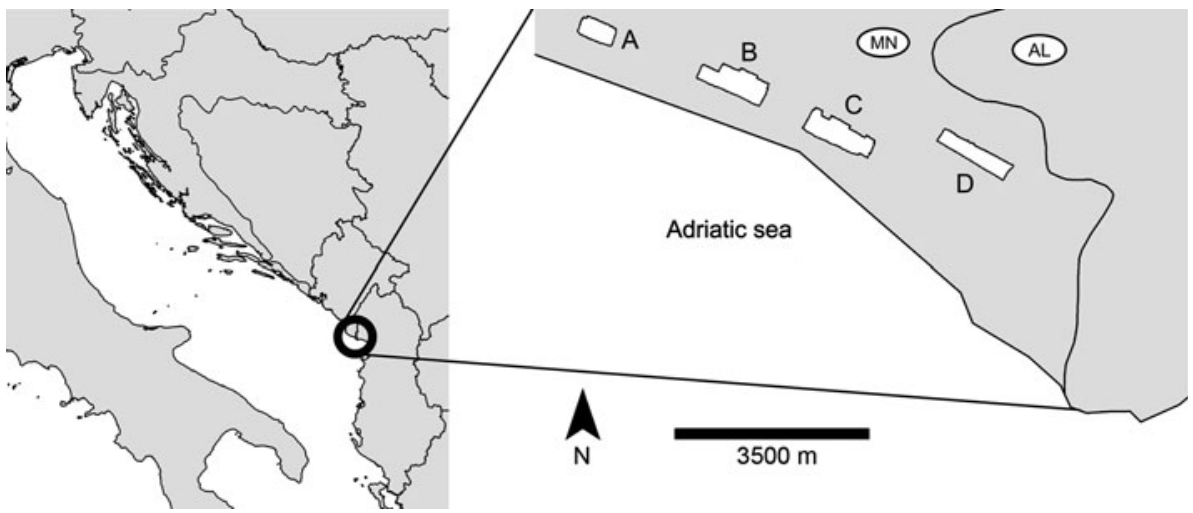


species through the region (Štumberger, personal communication). A total of 54 complete plot censuses were carried out, starting between 0600 and 1800 hours and lasting 30160 min at a single plot. The starting time of the censuses at each plot was varied in order to avoid time bias. The birds were counted and their sex determined from distances of at least $100 \mathrm{~m}$, to avoid disturbance. Observations were made with $8 \times 50$ binoculars and a $20-60 \times$ spotting scope. We refer to every record of spatially distinct Whinchats, either a solitary individual or a group, as a Whinchat unit. The Whinchat units were classified according to the number of individuals in the unit as (1) solitary birds, (2) small groups (2-3 individuals), (3) medium groups (4-10 individuals) and (4) large groups ( $\geq 11$ individuals). Every Whinchat unit was observed for $5 \mathrm{~min}$. Its activity during this interval was recorded and the exact area that it used was mapped (scale 1:3,000). The unit was classified as foraging if all individuals in the unit foraged within this interval or as non-foraging if none of the individuals foraged during this interval. No groups were encountered in which only some individuals foraged within the observation interval, although the intensity of foraging in some groups differed between individuals. We estimated overall foraging intensity of foraging units on ordinal scale: 1: less intensively foraging; 2 : intensively foraging. The areas used by Whinchat units were digitised using GIS software ESRI ArcView 3.1. Three zones were defined within the study area, pooled for all observations: (1) the foraging zone, used by Whinchat units for foraging, (2) the non-used zone where no Whinchat units were registered at any time of the censuses (forest fragments within the study plots were excluded) and (3) the non-foraging zone, used by non-foraging Whinchat units. During the observation interval some foraging Whinchat units moved across the habitat from one foraging patch to another, during which time their foraging activity ceased (see "Discussion"). These transient areas were included in the non-foraging zone. The non-foraging zone comprised only $1 \%$ of total study area and was not included in further analysis.

\section{Habitat data}

Eight habitat types were defined and mapped at the study plots. Their areas were obtained in GIS (Table 1). Fortythree non-overlapping sampling squares with 30 -m sides were placed at random in the study area using GIS. According to the case-control design (Hosmer and Lemeshow 2000; Keating and Cherry 2004), 16 sampling squares were placed within the foraging zone and 27 within the non-used zone. The following physiognomic variables of habitat were mapped within the sampling squares between 25 and 28 April: (1) natural perches (NP), (2) artificial perches (wire fence) (AP) and (3) vegetation types. Three distinct vegetation types were recognised: high herbal vegetation (HHV), low herbal vegetation (LHV) and open bushes (OB). Maps were digitised in GIS, and surface areas of vegetation types and lengths of wire fence were obtained.

The physiognomic variables were used in microhabitat analysis as independent (predictor) variables. The variable $\mathrm{NP}$ was quantified as the abundance of outstanding plant stems and small individual isolated bushes (at least 30\% above the rest of vegetation). The abundance was estimated

Table 1 Definitions, general characteristics, areas and proportions of the habitat types at the study plots

\begin{tabular}{|c|c|c|c|c|c|}
\hline Habitat type code & Habitat type & Definition & General characteristics & ha & $\%$ \\
\hline EXME & Extensive meadow & $\begin{array}{l}\text { Mown once a year, no mineral } \\
\text { fertilisers }\end{array}$ & $\begin{array}{l}\text { Abundant natural perches, high } \\
\text { diversity of plant species }\end{array}$ & 8.3 & 0 \\
\hline INME & Intensive meadow & $\begin{array}{l}\text { Mown more than once a year, } \\
\text { mineral fertilisers }\end{array}$ & $\begin{array}{l}\text { No or very few perches, low } \\
\text { diversity of plant species }\end{array}$ & 4.2 & 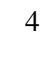 \\
\hline EXPA & Extensive pasture & $\begin{array}{l}\text { Pasture with low grazing density } \\
\text { (cattle, sheep or both) }\end{array}$ & $\begin{array}{l}\text { High physiognomic heterogeneity, } \\
\text { natural perches present in low to } \\
\text { high abundance }\end{array}$ & 12.8 & 13 \\
\hline INPA & Intensive pasture & $\begin{array}{l}\text { Pasture with high grazing density } \\
\text { (cattle, sheep or both) }\end{array}$ & $\begin{array}{l}\text { Very low vegetation (grazed), } \\
\text { physiognomic homogeneity, no } \\
\text { or very few perches }\end{array}$ & 29.8 & 30 \\
\hline ARLA & Arable land & Ploughed field & No plants, bare ground—soil & 1.2 & . \\
\hline OPED & Open edge & $\begin{array}{l}\text { 30-m-wide band on the borders } \\
\text { between pastures and/or } \\
\text { meadows }\end{array}$ & $\begin{array}{l}\text { Wire fences or hedgerows, high } \\
\text { physiognomic heterogeneity }\end{array}$ & 21.3 & 21 \\
\hline FOED & Forest edge & $\begin{array}{l}\text { 30-m-wide band along forest } \\
\text { patches }\end{array}$ & Immediate proximity of forest & 17.5 & 18 \\
\hline FOFR & Forest fragment & $\begin{array}{l}\text { Patch of forest inside cultivated } \\
\text { area }\end{array}$ & Deciduous tree species & 4.0 & \\
\hline
\end{tabular}


in the field according to the following ordinal scale: 0: no natural perches; 1 : some natural perches; 2 : considerable amount of natural perches; 3: many natural perches. The variable AP was quantified as the length of wire fence inside a sampling square. The lengths were classified to six length classes: $0: 0 \mathrm{~m} ; 1: 1-10 \mathrm{~m} ; 2: 11-20 \mathrm{~m} ; 3: 21-$ $30 \mathrm{~m} ; 4: 31-40 \mathrm{~m} ; 5: 41-50 \mathrm{~m}$. The vegetation types (HHV, LHV, OB) were quantified as surface areas in square metres. HHV was defined as herbal vegetation which was generally higher than $20 \mathrm{~cm}$, LHV as herbal vegetation which was generally lower than $20 \mathrm{~cm}$ and $\mathrm{OB}$ as herbal vegetation overgrown with bushes which covered at least $25 \%$ of the patch surface. When the bushes were isolated and covered less than $25 \%$ of the patch surface, they were classified as natural perches (NP) within HHV or LHV.

\section{Data analysis}

Using $\chi^{2}$ test, we tested whether time of the day, date, habitat type or unit size affected a Whinchat unit's foraging activity (no foraging/less intensive foraging/intensive foraging). Furthermore, using the Cochran-Mantel-Haenszel test, we tested whether there was a difference in the proportion of foraging units between solitaries and groups, after controlling for habitat type. The data used in the test were: foraging (yes/no) and habitat type as control factors, and unit size (solitary/group) as an additional control factor. Three habitat types where $85 \%$ of the Whinchat units foraged (OPED, EXPA and INPA), and two classes of units: (1) solitary and (2) group (joint size classes 2-3, 4-10 and 11-29) were used in the analysis.

Following Block and Brennan (1993), our study was carried out at macrohabitat and microhabitat spatial levels. At the macrohabitat level, we tested whether Whinchat units used habitat types according to their availability, using $\chi^{2}$ test. Furthermore, we did all possible pairwise comparisons of habitat types according to use by Whinchat units, using $\chi^{2}$ tests with Bonferonni correction. Only those habitat types which exceeded $10 \%$ of the total study area (OPED, FOED, EXPA and INPA) were included in this analysis.

At the microhabitat level, we modelled the use of a patch (represented by a sampling square) by foraging Whinchats in relation to physiognomic variables. Modelling was carried out in R software using the informationtheoretic approach (Burnham and Anderson 2002) and was considered exploratory. Information in the data was modelled with logistic regression (logit link function) since the dependent variable (Ufor-use of a patch by foraging Whinchats) was binary (used/not used) and independent variables (physiognomic variables) were continuous and discrete (Tabachnick and Fidell 2001). Besides the five physiognomic variables obtained in the field (NP, AP, HHV, LHV and OB), an additional independent variable Shannon-Wiener index was calculated from the proportions of vegetation types in a sampling square (Krebs 1999) and was used as index of heterogeneity of vegetation types (HVT). We calculated variance inflation factors (VIF) scaled versions of the multiple correlation coefficients between each of the six variables and the rest of the independent variables-to detect potential multicolinearity between the independent variables. Where VIF was larger than 10 or the tolerance value was less than 0.1 , the variable was excluded (Montgomery and Peck 1982; Neter et al. 1990; López-López et al. 2006). According to these criteria, the variable LHV was excluded from further analysis.

Using the five remaining independent variables (Fig. 2), all possible additive models and the null model (intercept only) were constructed. Both vegetation types (HHV + OB) were included simultaneously in models, thus 16 models were constructed (Table 2). All models were ranked according to the second-order information criterion $\mathrm{AIC}_{\mathrm{c}}$, since the ratio $n / K$ was 8.6. Likelihoods and probabilities $\left(w_{i}\right)$ were calculated for all models, and relative variable importance $\left(w_{+}(j)\right)$ was calculated for each variable in the set of models. $\mathrm{AIC}_{\mathrm{c}}$ differences $\left(\Delta_{i}\right)$, relative to the smallest $\mathrm{AIC}_{\mathrm{c}}$ value in the set of models, were used as criteria for model selection and inference (Burnham and Anderson 2002; Johnson and Omland 2004).

Goodness-of-fit of the global model (Ufor $\sim \mathrm{HHV}+$ $\mathrm{OB}+\mathrm{NP}+\mathrm{AP}+\mathrm{HVT}$ ) was calculated using nonparametric bootstrap (Crawley 2007). The rank of deviance of the global model was determined in sorted deviances of simulated models (100 bootstraps) and proved a good model fit $(P=0.22)$ and justified inference from reduced models. Since we used a random case-control sampling

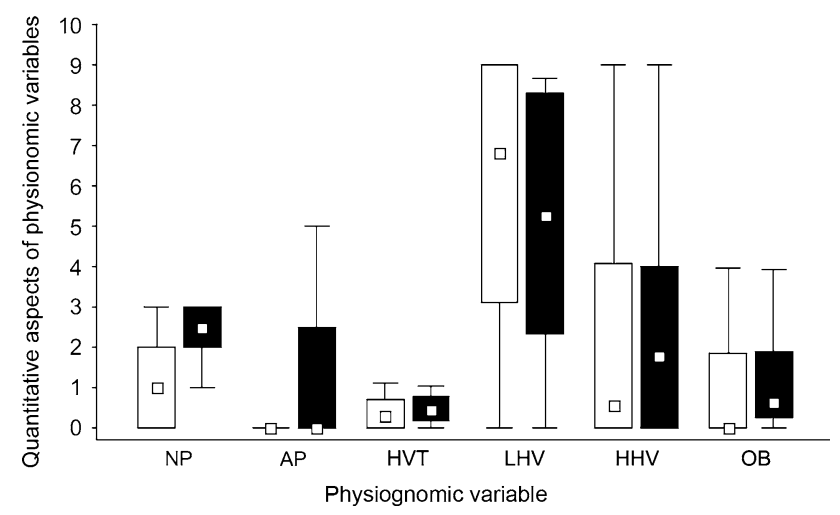

Fig. 2 Differences in physiognomic variables between the area used by Whinchats (Saxicola rubetra) for foraging (black boxes) and unused area (empty boxes). The boxes are quartiles, are whiskers minima and maxima, and the squares inside the boxes are medians. Units for $L H V, H H V$ and $O B$ are $\mathrm{m}^{2} \times 0.01$ 
Table 2 Logistic regression models with physiognomic variables as independent variables predicting use of a patch by foraging Whinchats (Saxicola rubetra)

\begin{tabular}{|c|c|c|c|c|c|c|}
\hline & Model & $K$ & $\mathrm{AIC}_{\mathrm{c}}$ & $\Delta_{i}$ & Model likelihood & $w_{i}$ \\
\hline 1 & NP & 2 & 46.255 & $\mathbf{0 . 0 0}$ & 1.000 & 0.41 \\
\hline 2 & $\mathbf{N P}+\mathbf{A P}$ & 3 & 47.180 & 0.93 & 0.630 & 0.26 \\
\hline 3 & $\mathrm{HVT}+\mathrm{NP}$ & 3 & 48.553 & 2.30 & 0.317 & 0.13 \\
\hline 4 & $\mathrm{HVT}+\mathrm{NP}+\mathrm{AP}$ & 4 & 49.612 & 3.36 & 0.187 & 0.08 \\
\hline 5 & $\mathrm{HHV}+\mathrm{OB}+\mathrm{NP}$ & 4 & 49.888 & 3.63 & 0.163 & 0.07 \\
\hline 6 & $\mathrm{NP}+\mathrm{AP}+\mathrm{HHV}+\mathrm{OB}$ & 5 & 51.273 & 5.02 & 0.081 & 0.03 \\
\hline 7 & $\mathrm{HHV}+\mathrm{OB}+\mathrm{HVT}+\mathrm{NP}$ & 5 & 52.355 & 6.10 & 0.047 & 0.02 \\
\hline 8 & $\mathrm{HHV}+\mathrm{OB}+\mathrm{NP}+\mathrm{AP}+\mathrm{HVT}$ & 6 & 53.763 & 7.51 & 0.023 & 0.01 \\
\hline 9 & $\mathrm{AP}$ & 2 & 58.375 & 12.12 & 0.002 & 0.00 \\
\hline 10 & Null & 1 & 58.863 & 12.61 & 0.002 & 0.00 \\
\hline 11 & HVT & 2 & 59.928 & 13.67 & 0.001 & 0.00 \\
\hline 12 & $\mathrm{HVT}+\mathrm{AP}$ & 3 & 60.165 & 13.91 & 0.001 & 0.00 \\
\hline 13 & $\mathrm{HHV}+\mathrm{OB}$ & 3 & 62.676 & 16.42 & 0.000 & 0.00 \\
\hline 14 & $\mathrm{HHV}+\mathrm{OB}+\mathrm{AP}$ & 4 & 62.750 & 16.50 & 0.000 & 0.00 \\
\hline 15 & $\mathrm{HHV}+\mathrm{OB}+\mathrm{HVT}$ & 4 & 64.644 & 18.39 & 0.000 & 0.00 \\
\hline 16 & $\mathrm{HHV}+\mathrm{OB}+\mathrm{HVT}+\mathrm{AP}$ & 5 & 65.133 & 18.88 & 0.000 & 0.00 \\
\hline
\end{tabular}

The models with substantial support from the data are in bold

$K$ Number of estimable parameters in model, $\mathrm{AIC}_{\mathrm{c}}$ a second-order Akaike's information criterion, $\Delta_{i} \mathrm{AIC}_{\mathrm{c}}$ differences, relative to the smallest $\mathrm{AIC}_{\mathrm{c}}$ value in the set of models, $w_{i}$ Akaike weights $N P$ natural perches, $A P$ artificial perches, $H H V$ high herbal vegetation, $L H V$ low herbal vegetation, $O B$ open bushes, $H V T$ heterogeneity of vegetation types

design, we interpret parameter estimates of selected models in terms of odds ratios (Keating and Cherry 2004).

\section{Results}

We recorded 71 Whinchat units (47 foraging, 24 non-foraging). Percentages of solitary birds, small, medium and large Whinchat groups were 22, 30, 37 and $11 \%$, respectively. The total number of observed Whinchats was 365 (261 males, 104 females). Minimum, maximum and average numbers of Whinchats in a unit were 1, 29 and $5.1 \pm 0.6$ (SD), respectively. A total of $96 \%$ of all observed Whinchats were members of groups of different sizes and $4 \%$ were solitaries, while $87 \%$ of all observed Whinchats belonged to foraging groups ( $7 \%$ to small groups, $46 \%$ to medium groups, $34 \%$ to large groups) and $1 \%$ were foraging solitaries, with $12 \%$ being non-foraging Whinchats, mainly solitaries and members of small groups.

There was a strong association between foraging activity of units and their size $\left(\chi^{2}=32.16, d f=6, P<0.001\right.$; Fig. 3). There was no association between foraging activity of units and hours $\left(\chi^{2}=15.40, d f=22, P=0.844\right)$ nor between foraging activity of units and days during the study $\left(\chi^{2}=33.5, d f=30, P=0.300\right)$. The selected habitat types did not differ significantly between intensively foraging, less intensively foraging and non-foraging

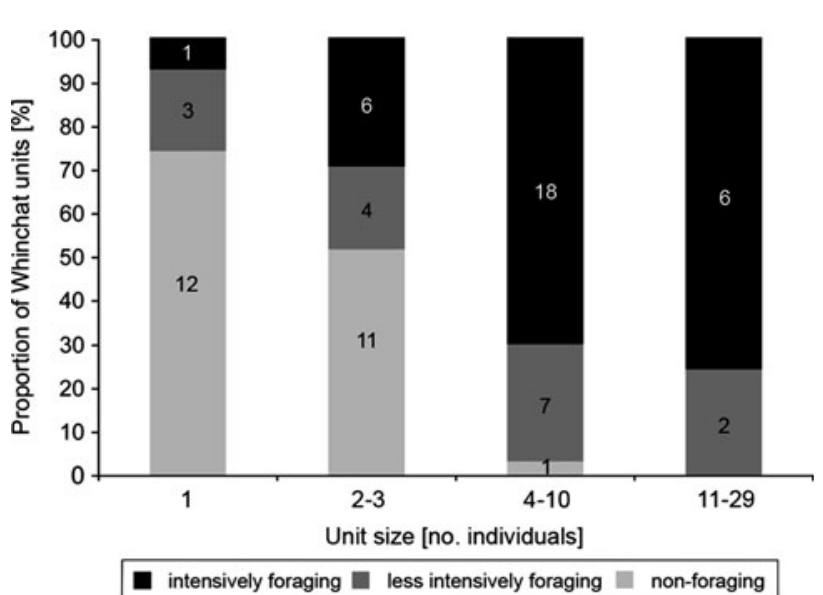

Fig. 3 Proportions of intensively foraging, less intensively foraging and non-foraging Whinchat units in relation to unit size. The numbers in the bars are the frequencies of observed Whinchat units

Whinchat units $\left(\chi^{2}=8.66, d f=8, P=0.371\right)$. There was a significant difference in the proportion of foraging units between the solitaries and groups, after controlling for habitat type $\left(\chi_{\mathrm{MH}}^{2}=15.210, d f=1, P<0.001\right)$. In each of the three habitat types (OPED, EXPA and INPA), the proportions of foraging to non-foraging solitaries were smaller than proportions of foraging to non-foraging groups. 
Whinchats significantly selected particular habitats and avoided others $\left(\chi^{2}=42.06, d f=3, P<0.001\right.$; Fig. 4). The most preferred habitat type was open edge. Surface areas of the foraging, non-foraging and non-used zones were 6, 1 and 89 ha, respectively. The remaining 4 ha within the study area (100 ha) were forest islands.

Of the physiognomic variables, the natural and artificial perches best predicted the use of a patch by foraging Whinchats. In the set of models, two were supported substantially by the data $\left(\Delta_{i} \leq 2\right)$, five considerably less well supported $\left(2<\Delta_{i} \leq 7\right)$, and nine essentially not supported by the data $\left(\Delta_{i}>7\right)$ (Table 2$)$. The predictor variables for the presence of foraging Whinchat units were, in order of importance, NP, AP, HVT, $\mathrm{HV}$ and $\mathrm{OB}$, with relative importance weights $1,0.38,0.24,0.13$ and 0.13 , respectively. Increase of the parameter value of the most important variable NP by one level means four times the odds that the habitat is selected by a Whinchat unit for foraging (Table 3).

\section{Discussion}

The great majority of Whinchats foraged in groups, indicating the preference for social foraging on spring migration. Small passerine birds travel at night solitarily or in very loose associations (Bruderer 1997). The groups of Whinchats observed on the Montenegrin coast had therefore most probably formed at the stopover site in order to forage socially. Most of the medium and large groups foraged intensively, while high proportions of solitaries and small groups foraged less intensively or did

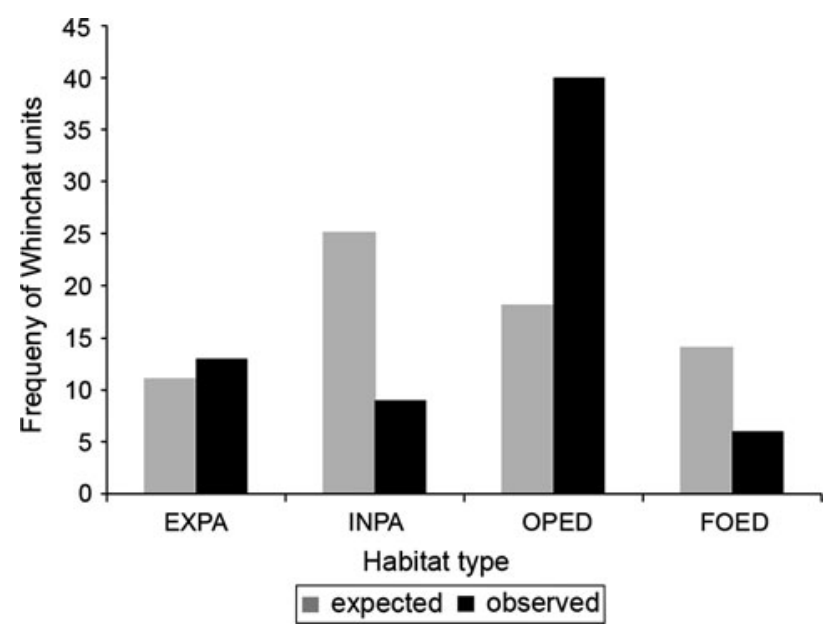

Fig. 4 Expected and observed use of habitat types by Whinchat units. Expected frequencies were calculated from proportions of available habitat types (see Table 1 for habitat type codes)
Table 3 Coefficients and odds ratios for models with substantial support from the data

\begin{tabular}{lllllll}
\hline Model & \multicolumn{4}{l}{ Variable in the model } & \\
\cline { 2 - 3 } & $\mathrm{NP}$ & & & $\mathrm{AP}$ & & Intercept \\
\cline { 2 - 3 } \cline { 5 - 6 } & $\beta$ & $\exp (\beta)$ & & $\beta$ & $\exp (\beta)$ & \\
\hline $\mathrm{NP}$ & 1.471 & 4.35 & & & -3.321 \\
$\mathrm{NP}+\mathrm{AP}$ & 1.437 & 4.21 & & 0.278 & 1.32 & -3.523 \\
\hline
\end{tabular}

not forage at all. These individuals were either less successful in finding a food-rich patch or were momentarily not motivated for foraging. Although the primary goal of birds on migration stopover is refuelling, they also spend time on other activities (e.g. resting, being cautious, defending temporary territories) (Dierschke et al. 2003). It is possible that the non-foraging solitaries and small groups in our study were the newcomers having a rest after a long non-stop flight (Schwilch et al. 2002) and which had not yet encountered their congeners to join for active foraging.

Draulans and van Vessem (1982) reported that foraging intensity of individual Whinchats was higher in larger groups in homogenous environment. They suggested that foraging Whinchats flush the insects which become available to other group members and this enhances their foraging intensity. Whinchats at the Montenegrin stopover tended to maximise foraging intensity through social foraging since most of medium and large groups foraged intensively. However, medium groups were much more common than large groups and more individuals were members of medium groups. If foraging intensity of the Whinchat groups in our study was dependent only on group size, like in the study of Draulans and van Vessem (1982), then Whinchats would tend to forage in large groups. Unlike the study of Draulans and van Vessem, our study was done in a heterogeneous environment. We suggest that, regarding the intensity of foraging, the optimal Whinchat foraging group size also depends on abundance and distribution of food in the environment. However, we do not have any data on insect abundance in our study sites to support this hypothesis. The groups can change in size during the stopover, since there are no tight bonds between individuals (Bastian and Bastian 1996).

Perches are used by Whinchats for singing and foraging and have been shown to be a limiting factor in the settlement of Whinchats on the breeding grounds (Labhardt 1988; Oppermann 1990; Bastian and Bastian 1996). Whether they also influence the distribution of Whinchats at migration stopover sites has, however, not been 
determined. We argue that the intensive pastures at the Montenegrin coast were avoided due to lack of perches and not because of poor insect availability. Regular observation in this habitat type of other foraging migrating insectivore passerines (Northern Wheatears Oenanthe oenanthe, Yellow Wagtails Motacilla flava), which normally forage by pecking, suggests that the invertebrate food was also present on intensive pastures. Open edge and extensive pastures, both characterised by abundant perches, were selected preferentially by Whinchat units. We propose that the perches are an important cue for habitat selection and an important feature for habitat exploration by Whinchats within the stopover site. When the Whinchat groups moved across the habitat they consistently used perches. Some groups were observed moving across habitat in such a manner that individuals alternated in making short flights between natural perches or along the wire fence. From time to time some of them performed foraging flights which indicated scanning of the microhabitat for food. When the group encountered a suitable patch (probably assessed as high frequency of food items encountered), it stopped, started to forage intensively and stayed there for some time (even an hour or more).

Specific vegetation types (HHV, OB) did not affect foraging patch selection. The type of herbal vegetation cover is important in Whinchats' choice of habitat during the breeding season, because it provides proper cover for the nest (Oppermann 1990; Denac 2007). We expected that the heterogeneity of vegetation types (HVT) would positively affect the selection of a foraging patch, because the abundance of grassland invertebrates is usually higher in heterogeneous than in homogenous herbal layers (Dennis et al. 1998; Britschgi et al. 2006). However, the models that contained this variable were less supported by the data and the importance of HVT relative to the most important variable (NP) was fairly low.

We conclude that Whinchats at the spring migration stopover site on the Montenegrin coast prefer social to solitary foraging. When they remain solitary or in very small groups, it is most probably because they have not encountered congeners. We also propose that perches are an essential habitat feature, substantially affecting habitat use and foraging patch selection by Whinchats in mosaic cultural landscapes on migration stopovers. Other physiognomic factors of open grasslands are likely to be important only to the extent to which they affect invertebrate abundance. The conservation efforts at Whinchat stopover sites should aim at preserving invertebrate rich habitat types with abundant perches and the presence of open edge. This can be achieved through extensive pasture characterised by low grazing density and small pastures lined off with wire fence and hedgerows.

\section{Zusammenfassung}

Soziale Futtersuche und Habitatnutzung bei einem langstreckenziehenden Sperlingsvogel, dem Braunkehlchen Saxicola rubetra, an einem Frühjahrs-Rastplatz an der südostadriatischen Küste

Die Vorliebe für die Futtersuche in Gruppen und der Einfluss physiognomischer Faktoren eines Habitats auf seine Nutzung durch futtersuchende Braunkehlchen (Saxicola rubetra) wurde während einer Rast auf dem Frühjahrszug in einer Mosaik-Kulturlandschaft an der südostadriatischen Küste untersucht. Jede Erfassung einzelner Braunkehlchen oder räumlich abgegrenzter Braunkehlchen-Gruppen wurde als eine Braunkehlchen-Einheit betrachtet. Die Einheiten wurden als intensiv nach Futter suchend, weniger intensiv nach Futter suchend oder nicht nach Futter suchend klassifiziert und in vier Größenklassen aufgeteilt. Der Einfluss physiognomischer Habitatfaktoren auf die Habitatnutzung durch futtersuchende Braunkehlchen-Einheiten wurde modelliert. Alle möglichen additiven Modelle, die eine Logit-Link-Funktion benutzen, wurden aus fünf unabhängigen physiognomischen Variablen erstellt: (a) natürliche Sitzplätze (NP), (b) künstliche Sitzplätze (AP), (c) hochwüchsige krautige Vegetation (HHV), (d) offenes Gesträuch (OB) und (e) Heterogenität der Vegetationstypen (HVT). Die Variablen HHV und OB wurden gleichzeitig in die Modelle aufgenommen. Anhand von Akaikes Informationskriterium zweiter Ordnung AICc. wurden die Modelle ausgewählt, die von den Daten am besten gestützt wurden. Zwei dieser Modelle enthielten die Variable(n) (a) NP und (b) $\mathrm{NP}+\mathrm{AP}$. Die relativen Gewichtungen der physiognomischen Variablen NP, AP, HVT, HHV und OB betrugen $1,0,38,0,24,0,13$ und 0,13 . Sitzplätze waren daher die wichtigsten physiognomischen Habitatfaktoren, welche die Habitatnutzung durch Braunkehlchen in einer MosaikKulturlandschaft beeinflussten. Die große Mehrheit der Braunkehlchen suchte in Gruppen nach Futter, und der Anteil intensiv nach Futter suchender BraunkehlchenEinheiten nahm mit der Größe der Einheit zu. Dies führte zu der Schlussfolgerung, dass Braunkehlchen am Frühjahrs-Rastplatz an der südostadriatischen Küste die soziale der individuellen Futtersuche vorzogen.

Acknowledgments The study was supported by the Slovenian Research Agency, through the programme of financing the postgraduate education of junior researchers, and by Euronatur foundation. We thank the Montenegrin National Institute for Protection of Nature for enabling us to carry out the fieldwork. We thank Borut Štumberger and Tomaž Skrbinšek for advice during the research and to dr. Reto Spaar, dr. Davorin Tome and an anonymous reviewer for their valuable comments on the manuscript. 


\section{References}

Alerstam T, Hedenström A (1998) The development of bird migration theory. J Avian Biol 29:343-369

Alerstam T, Lindström A (1990) Optimal bird migration: the relative importance of time, energy, and safety. In: Gwinner E (ed) Bird migration: physiology and ecophysiology. Springer, Berlin, pp 331-351

Bairlein F (1983) Habitat selection and associations of species in European passerine birds during southward, post-breeding migrations. Ornis Scand 14:239-245

Bairlein F (1992) Morphology - habitat relationships in migrating songbirds. In: Hagan JMI, Johnston DW (eds) Ecology and conservation of Neotropical migrant landbirds. Smithsonian Institution Press, Washington, pp 356-369

Bastian A, Bastian H-V (1996) Das Braunkehlchen: Opfer der ausgeräumten Kulturlandschaft. AULA, Wiesbaden

Bibby CJ, Green RE (1981) Autumn migration strategies of reed and sedge Warblers. Ornis Scand 12:1-12

BirdLife International (2004) Birds in Europe: population estimates trends and conservation status. BirdLife International, Cambridge

Block WM, Brennan LA (1993) The habitat concept in ornithology: theory and applications. Curr Ornithol 11:35-91

Britschgi A, Spaar R, Arlettaz R (2006) Impact of grassland farming intensification on the breeding ecology of an indicator insectivorous passerine, the whinchat Saxicola rubetra: lessons for overall Alpine meadowland management. Biol Conserv 130:193-205

Bruderer B (1997) The study of bird migration by radar. Part 2: major achievements. Naturwissenschaften 84:45-54

Burnham KP, Anderson DR (2002) Model selection and multimodel inference. A practical information-theoretic approach, 2nd edn. Springer, New York

Chernetsov N (2006) Habitat selection by nocturnal passerine migrants en route: mechanisms and results. J Ornithol 147:185-191

Crawley MJ (2007) The R Book. Wiley, Chichester

Delingat J, Dierschke J (2000) Habitat utilization by northern wheatears (Oenanthe oenanthe) stopping over on an offshore island during migration. Vogelwarte 40:271-278

Denac D (2007) Populacijska dinamika repaljščice (Saxicola rubetra) $\mathrm{v}$ mozaiku nižinskih habitatnih tipov. Univerza v Mariboru, Maribor

Dennis P, Young MR, Gordon IJ (1998) Distribution and abundance of small insects and arachnids in relation to structural heterogeneity of grazed, indigenous grasslands. Ecol Entomol 23:253264

Dierschke V, Delingat J, Schmaljohann H (2003) Time allocation in migrating northern wheatears (Oenanthe oenanthe) during stopover: is refuelling limited by food availability or metabolically? J Ornithol 144:33-44

Donovan TM, Thompson FRI (2001) Modeling the ecological trap hypothesis: a habitat and demographic analysis for migrant songbirds. Ecol Appl 11:871-882

Draulans D, van Vessem J (1982) Flock size and feeding behaviour of migrating whinchats Saxicola rubetra. Ibis 124:347-351

Duckworth JW (1994) Habitat selection by migrants redstarts Phoenicurus phoenicurus and whinchat Saxicola rubetra in lowland English farmland. Ringing Migrat 15:119-122

Ekman J, Hake M (1988) Avian flocking reduces starvation risk: an experimental demonstration. Behav Ecol Sociobiol 22:9194

Giraldeau L-A, Caraco T (2000) Social foraging theory, 2nd edn. Princeton University Press, Chichester
Glutz von Blotzheim UN (1988) Saxicola rubetra (Linnaeus 1758) - Braunkehlchen. In: Glutz von Blotzheim UN (ed) Handbuch der Vögel Mitteleuropas, 11/I. AULA, Wiesbaden, pp 392-446

Hedenström A, Alerstam T (1997) Optimum fuel loads in migratory birds: distinguishing between time and energy minimization. J Theor Biol 189:227-234

Horch P, Rehsteiner U, Berger-Flückiger A et al (2008) Bestandsrückgang des Braunkehlchens Saxicola rubetra in der Schweiz, mögliche Ursachen und Evaluation von Fördermassnahmen. Ornithol Beob 105:267-298

Hosmer DW, Lemeshow S (2000) Applied logistic regression analysis, 2nd edn. Wiley, New York

Hutto RL (1985a) Habitat selection by nonbreeding, migratory land birds. In: Cody ML (ed) Habitat selection in birds. Academic, New York, pp 455-476

Hutto RL (1985b) Seasonal changes in the habitat distribution of transient insectivorous birds in southeastern Arizona: competition mediated? Auk 102:120-132

Johnson JB, Omland KS (2004) Model selection in ecology and evolution. Trends Ecol Evol 19:101-108

Keating KA, Cherry S (2004) Use and interpretation of logistic regression in habitat-selection studies. J Wild Manag 68:774789

Krebs CJ (1999) Ecological Methodology, 2nd edn. Addison-Wesley, New York

Labhardt A (1988) Siedlungsstruktur von Braunkelchen-Populationen auf zwei Höhenstufen der Westschweizer Voralpen. Beih Veröff Naturschutz Landschaftspflege Bad-Württ 51:139-158

López-López P, García-Ripollés C, Aguilar JM et al (2006) Modelling breeding habitat preferences of Bonelli's eagle (Hieraaetus fasciatus) in relation to topography, disturbance, climate and land use at different spatial scales. J Ornithol 147:97-106

Maccarone AD, Brzorad JN (2005) Foraging microhabitat selection by wading birds in a tidal estuary, with implications for conservation. Waterbirds 28:383-391

Martin TE, Karr JR (1986) Patch utilization by migrating birds: resource oriented? Ornis Scand 17:165-174

Montgomery DC, Peck EA (1982) Introduction to regression analysis. Wiley, New York

Moore FR, Gauthreaux SA Jr, Kerlinger P et al (1995) Habitat requirements during migration: important link in conservation. In: Martin TE, Finch DM (eds) Ecology and management of Neotropical migratory birds: a synthesis and review of critical issues. Oxford University Press, New York, USA, pp 121-144

Müller M, Spaar R, Schifferli L et al (2005) Effects of changes in farming of subalpine meadows on a grassland bird, the whinchat (Saxicola rubetra). J Ornithol 146:14-23

Neter J, Wasserman W, Kunter MH (1990) Applied linear statistical models, 3rd edn. Irwin, Columbus

Newton I (2008) The migration ecology of birds. Elsevier, London

Oppermann R (1990) Suitability of different vegetation structure types as habitat for the whinchat (Saxicola rubetra). Plant Ecol 90:109-116

Schaub M, Jenni L (2000) Fuel deposition of three passerine bird species along the migration route. Oecologia 122:306-317

Schneider-Jacoby M, Schwarz U, Sackl P (eds) (2006) Rapid assessment of the ecological value of the Bojana-Buna delta (Albania / Montenegro). Euronatur, Radolfzell

Schwilch R, Piersma T, Holmgren NMA et al (2002) Do migratory birds need a nap after long non-stop flight? Ardea 90:149-154

Suhonen J (1993) Predation risk influences the use of foraging sites by tits. Ecology 74:1197-1203

Szekely T, Sozou PD, Houston AI (1991) Flocking behaviour of passerines: a dynamic model for the non-reproductive season. Behav Ecol Sociobiol 28:203-213 
Tabachnick BG, Fidell LS (2001) Using multivariate statistics, 4th edn. Allyn and Bacon, Boston

Walther BA, Gosler AG (2001) The effects of food availability and distance to protective cover on the winter foraging behaviour of tits (Aves: Parus). Oecologia 129:312-320
Wikelski M, Tarlow EM, Raim A et al (2003) Avian metabolism: costs of migration in free-flying songbirds. Nature 423:704

Yong W, Finch DM, Moore FR et al (1998) Stopover ecology and habitat use of migratory Wilson's warblers. Auk 115:829-842 